\title{
The Robust Self-Assembling Tubular Nanostructures Formed by gp053 from Phage vB_EcoM_FV3
}

\author{
Eugenijus Šimoliūnas ${ }^{1, *}$, Lidija Truncaitè ${ }^{1}$, Rasa Rutkienè ${ }^{1}$, Simona Povilonienè ${ }^{1}$, \\ Karolis Goda ${ }^{2}$, Algirdas Kaupinis ${ }^{3}$, Mindaugas Valius ${ }^{3}$ and Rolandas Meškys ${ }^{1}$ (D) \\ 1 Department of Molecular Microbiology and Biotechnology, Institute of Biochemistry, Life Sciences Centre, \\ Vilnius University, Saulètekio av. 7, LT-10257 Vilnius, Lithuania; lidija.truncaite@bchi.vu.lt (L.T.); \\ rasa.rutkiene@bchi.vu.lt (R.R.); simona.poviloniene@bchi.vu.lt (S.P.); rolandas.meskys@bchi.vu.lt (R.M.) \\ 2 Sector of Microtechnologies, Institute of Biotechnology, Life Sciences Centre, Vilnius University, \\ Saulètekio av. 7, LT-10257 Vilnius, Lithuania; karolis.goda@gmail.com \\ 3 Proteomics Centre, Institute of Biochemistry, Life Sciences Centre, Vilnius University, Saulètekio av. 7, \\ LT-10257 Vilnius, Lithuania; algirdas.kaupinis@gf.vu.lt (A.K.); mindaugas.valius@bchi.vu.lt (M.V.) \\ * Correspondence: eugenijus.simoliunas@bchi.vu.lt; Tel.: +370-6507-0467
}

Received: 3 December 2018; Accepted: 8 January 2019; Published: 11 January 2019

\begin{abstract}
The recombinant phage tail sheath protein, gp053, from Escherichia coli infecting myovirus vB_EcoM_FV3 (FV3) was able to self-assemble into long, ordered and extremely stable tubular structures (polysheaths) in the absence of other viral proteins. TEM observations revealed that those protein nanotubes varied in length $(\sim 10-1000 \mathrm{~nm})$. Meanwhile, the width of the polysheaths $(\sim 28 \mathrm{~nm})$ corresponded to the width of the contracted tail sheath of phage FV3. The formed protein nanotubes could withstand various extreme treatments including heating up to $100^{\circ} \mathrm{C}$ and high concentrations of urea. To determine the shortest variant of gp053 capable of forming protein nanotubes, a set of $\mathrm{N}$ or/and C-truncated as well as poly-His-tagged variants of gp053 were constructed. The TEM analysis of these mutants showed that up to 25 and 100 amino acid residues could be removed from the $\mathrm{N}$ and $\mathrm{C}$ termini, respectively, without disturbing the process of self-assembly. In addition, two to six copies of the gp053 encoding gene were fused into one open reading frame. All the constructed oligomers of gp053 self-assembled in vitro forming structures of different regularity. By using the modification of cysteines with biotin, the polysheaths were tested for exposed thiol groups. Polysheaths formed by the wild-type gp053 or its mutants possess physicochemical properties, which are very attractive for the construction of self-assembling nanostructures with potential applications in different fields of nanosciences.
\end{abstract}

Keywords: self-assembly; nanotubular structures; tail sheath protein; bacteriophage vB_EcoM_FV3

\section{Introduction}

Over the past decades, the construction of various nanostructures, based on self-assembling biomolecules, is of special interest for both an understanding of the fundamental point of view as well as due to the enormous potential for application in industry, medicine and many other areas [1-3]. Self-assembling structures open up exciting opportunities for the development of various tools, including biosensors, energy storage devices, drug delivery systems and nanobiopolymeric scaffolds [4-7]. Therefore, it is not surprising that viruses, including bacteriophages, have been used for the preparation of nanoscaled materials [8-15].

Filamentous bacteriophage M13 and its relatives are the phages of choice, most often used for the construction of genetically engineered viruses, which have been adapted to build phage-based nanosensors, liquid crystals and films [16,17], micro- and nanofibers [14,18], as well as having use in tissue regeneration and to build other functional materials [19-23], or to fabricate nanorings [24]. 
The construction of self-assembling structures, made from the genetically engineered recombinant proteins of tailed bacteriophages, including podoviruses P22, phi29 [25,26] and myovirus T4 $[4,27,28]$, have also been reported.

During the morphogenesis process of the tailed bacteriophages, the assembly pathways of the structural components follow a strict order and consist of many steps where the subsequent attachment of proteins is controlled by different mechanisms [29-31]. Thus, tail sheath proteins alongside tail tube proteins constitute a major part of the contractile tail of myoviruses [31,32]. The polymerisation of the tail sheath proteins, which assemble around the tail tube, starts at the tail tip complex (the baseplate) and is propagated to the end of the tube. The sheath subunits arrange into a stack of hexameric rings, rotated relative to each other, thus creating a 6-start helix [33,34]. During the process of virion assembly inside the cell, the length of the tail sheath is determined by the length of the tail tape measure protein, which is used as a scaffold for the polymerisation of both tail tube and tail sheath proteins. When the sheath reaches the length of the tube, the tail terminator protein binds to the tail tube terminator protein and the last row of the tail sheath subunits to complete the tail, which then becomes available for attachment to the head $[31,33]$.

It has been demonstrated that, in the absence of the baseplate or the tail tube, the recombinant tail sheath proteins of bacteriophages self-assemble both in vivo and in vitro into tubular structures of variable lengths called polysheaths which have the same helical parameters as the contracted tail sheath [35-38]. The polysheath is a stable structure, which withstands treatment with various chemical and physical factors [39-41]. A number of deletion mutants of tail sheath proteins have also been constructed and analysed $[29,38,42,43]$.

In order to expand the current knowledge on biotechnologically attractive self-assembling structural proteins from phages, a tail sheath protein (gp053) of E. coli infecting myovirus vB_EcoM_FV3 (FV3) [44] was studied in detail. We showed that the recombinant gp053 self-assembled into long ordered and very stable polysheaths. In addition, the gp053 mutants harbouring the deletions at the $\mathrm{N}$ and/or $\mathrm{C}$ terminus, with or without the His-tag, as well as the genetically fused homooligomers of gp053 were constructed and their tendency to form nanostructures was analysed.

\section{Materials and Methods}

\subsection{Cloning Procedures}

The PCR fragment of gene 053 (GeneID: 14011712) from phage FV3 was obtained by amplification of the phage DNA using the primers presented in Supplementary Table S1. The purified PCR products were cleaved with NdeI and BamHI/XhoI (Thermo Fisher Scientific, Vilnius, Lithuania) and then inserted into the pET-16b or pET-21a (Novagene, Madison, WI, USA) vectors, digested with the appropriate restriction endonucleases. The resulting vectors were amplified in E. coli DH10B (Invitrogen, Dublin, Ireland) cells and verified by DNA sequencing. These vectors were used for the production of a recombinant full-length gp053 and the truncated gp053 mutants with various variations in length and His-tag (Supplementary Table S2). The construction scheme of the gp053 oligomers is presented in detail in Supplementary Figure S1.

\subsection{Protein Expression}

Protein production was carried out in the E. coli strain BL21 (DE3) (Novagene, Madison, WI, USA). The $15 \mathrm{ml}$ of cells that were transformed with the appropriate plasmid were grown at $37^{\circ} \mathrm{C}$ to an $\mathrm{OD}_{600}$ of 0.5 , induced with $0.1 \mathrm{mM}$ IPTG and then incubated at $30^{\circ} \mathrm{C}$ for 3 hours. The cells were harvested by centrifugation at $4000 \times g$ for $5 \mathrm{~min}$ at $4{ }^{\circ} \mathrm{C}$, resuspended in $1.5 \mathrm{~mL}$ TE $(20 \mathrm{mM}$ Tris- $\mathrm{HCl}(\mathrm{pH} 7.8))$ and $1 \mathrm{mM}$ EDTA, $4^{\circ} \mathrm{C}$ ) buffer solution and then disrupted by sonication. The cells with expressed His-tagged recombinant gp053 proteins, which were further purified by using a metal-chelating sorbent, were resuspended in $1.5 \mathrm{~mL}$ His-Wash (50 mM sodium phosphate buffer ( $\mathrm{pH} 7.7)$ ), $300 \mathrm{mM}$ $\mathrm{NaCl}, 50 \mathrm{mM}$ imidazole and $0.03 \%$ Triton $\mathrm{X}-100,4{ }^{\circ} \mathrm{C}$ ) buffer solution. The cells were sonicated on ice, 
in $2.0 \mathrm{~mL}$ tubes at $30 \%$ amplitude for $5 \mathrm{~min}$ of total $\mathrm{ON}$ time (30 s on $/ 30 \mathrm{~s}$ off) by using the Bandelin SonoPuls HD 2070 homogeniser (BANDELIN, Berlin, Germany). The crude extracts were centrifuged at $4{ }^{\circ} \mathrm{C}$ for $15 \mathrm{~min}$ at $21,000 \times g$ to remove cell debris. The cell-free extracts and pellets were directly analysed by SDS-PAGE as well as by TEM.

\subsection{Protein Purification}

The polysheaths formed by the recombinant gp053 were precipitated from the supernatant by the addition of ammonium sulphate to a final concentration of $10 \%$. After incubation for $10 \mathrm{~min}$ on ice and centrifugation at $9000 \times g$ for $15 \mathrm{~min}$ at $4{ }^{\circ} \mathrm{C}$, the supernatant was removed, and the pellet was suspended in TE buffer (1/10 of the initial volume) and stored at $4{ }^{\circ} \mathrm{C}$. The shorter, less ordered polysheaths were purified by the addition of ammonium sulphate to a final concentration of $15-20 \%$ and/or by repeated centrifugation at $9000 \times g$ for $15 \mathrm{~min}$ at $4{ }^{\circ} \mathrm{C}$. Alternatively, the recombinant His-tagged protein purification using the metal-chelating sorbent was performed by using the His-Spin Protein Miniprep kit (Zymo Research, Irvine, CA, USA) according to the manufacturer's recommendations. The concentration of the recombinant protein was determined by using a method described by Lowry et al. [45].

\subsection{Limited Proteolysis of Recombinant Proteins with Trypsin}

Trypsin $(2 \mathrm{mg} / \mathrm{mL})$ was added into the protein solution $(\sim 2 \mathrm{mg} / \mathrm{mL})$ to form a final protease:protein ratio of 1:100 $(w / w)$, and the solution was then incubated at $22{ }^{\circ} \mathrm{C}$. Aliquots $(10 \mu \mathrm{L})$ were withdrawn from the reaction mixture at different time intervals and mixed with $10 \mu \mathrm{L}$ of SDS sample buffer $(2 \times$ concentrated). The reaction was stopped by heating the solution in boiling water for $5 \mathrm{~min}$. The samples were analysed by electrophoresis in SDS-polyacrylamide gel.

\subsection{In-Gel Protein Digestion for Mass Spectrometry Analysis, Liquid Chromatography and Mass Spectrometry}

In-gel trypsin digestion was performed according to the protocol described by Hellman et al. [46]. LC-MS data were collected as described previously [47]. Briefly, the liquid chromatographic analysis was performed in a Waters Acquity ultra performance LC system (Waters Corporation, Wilmslow, UK). The peptide separation was performed on an Acquity UPLC HSS T3 $250 \mathrm{~mm}$ analytical column. The MS data were acquired using the Synapt G2 mass spectometer and Masslynx 4.1 software (Waters Corporation) in positive ion mode using data independent (DIA) acquisition (MSE).

\subsection{Labelling of gp053 Polysheaths with Neutravidin-Conjugated Gold Nanoparticles}

The labelling of polysheaths with gold nanoparticles was carried out according to the published procedure [48] with some modifications. The suspension of the purified recombinant gp053 was treated with $1 \mathrm{mM}$ of tris(2-carboxyethyl)phosphine (TCEP) (AppliChem, Darmstadt, Germany) to reduce possible disulphide bonds. The reduced protein was dialysed against PBS (pH 7.5) for $1 \mathrm{~h}$ at $22{ }^{\circ} \mathrm{C}$. After 1 hour of biotinylation at $22{ }^{\circ} \mathrm{C}$, the mixture was dialysed against PBS (pH 7.5) buffer. The efficiency of biotinylation was evaluated and the biotinylated polysheaths were incubated with neutravidin-conjugated $10 \mathrm{~nm}$ gold nanoparticles (Nanopartz, Loveland, CO, USA) as described previously [48]. The mixtures of polysheaths and nanoparticles were incubated for 1 to 5 days at $4{ }^{\circ} \mathrm{C}$. The incubation of non-biotinylated polysheaths with neutravidin-conjugated $10 \mathrm{~nm}$ gold nanoparticles was carried out under the same conditions.

\subsection{Transmission Electron Microscopy (TEM)}

The images of gp053 were obtained by transmission electron microscopy of the negatively-stained samples. Approximately $10 \mu \mathrm{L}$ of the diluted sample solution was directly applied on the carbon-coated nickel grid (Agar Scientific, Essex, UK), and the excess liquid was drained with filter paper before 
staining with two successive drops of $2 \%$ uranyl acetate $(\mathrm{pH} 4.5)$. The prepared sample was dried and examined with a Morgagni 268(D) transmission electron microscope (FEI, Hillsboro, OR, USA).

\subsection{Bioinformatics and Molecular Modeling}

The bioinformatics analysis of gp053 was performed using the Fasta-Nucleotide, Fasta-Protein, BLASTP, Transeq [49] and Clustal Omega [50]. The phylogenetic analysis was conducted using MEGA version 5 [51]. The Protein Information Resource (PIR) server was used for calculating the predicted molecular mass of the recombinant protein [52]. The search for the gp053 fold was conducted using the HHpred server [53-55]. The I-TASSER server [56,57] was used to model the whole gp053. UCSF Chimera $[58,59]$ was used for the visualisation and analysis of the predicted molecular structure of gp053.

\section{Results}

\subsection{Bioinformatics Analysis}

Based on the results of the bioinformatics analysis, the tail sheath protein encoded by gene 053 (GeneID: 14011712) of the enterobacteria phage FV3 [44] had the closest identity (96-99\%) to the tail sheath proteins from the eleven Escherichia infecting bacteriophages, which belonged to the genus V5virus within the subfamily Vequintavirinae (Supplementary Table S3).

The HHpred analysis of the amino acid sequence of gp053 revealed that it corresponded to the fold of the two tail sheath proteins of bacteriophages. Hence, the residues 8 to 442 of gp053 were predicted to adopt the fold of the tail sheath protein from Staphylococcus phage phi812 (PDB ref 5LI4) with a probability of 97.05 ( $E$-value, 0.047 ), whereas C-terminal fragment of gp053 (residues 258 to 442) was predicted to adopt the fold of the C-terminal fragment (residues 470 to 643) of the tail sheath protein, gp18, of the phage T4 (PDB ref 3J2M) with a probability of $97.2\left(E\right.$-value, $\left.3.4 \times 10^{-4}\right)$. In addition, the HHpred analysis revealed that the predicted fold of gp053 was similar to the contractile phage-like structures from bacteria. The residues 1 to 441 of gp053 were predicted to adopt the fold of the R-type pyocins from Clostridium difficile (PDB ref 6GKW) and Pseudomonas aeruginosa (PDB ref 3J9Q) with a probability of 99.51 ( $E$-value, $1.2 \times 10^{-14}$ ) and 98.6 ( $E$-value, $\left.9.9 \times 10^{-7}\right)$, respectively. The residues 18 to 442 were aligned with the tail sheath protein encoded by gene lin 1278 from the prophage infecting Listeria innocua (PDB ref 3LML) with a probability of $98.5\left(E\right.$-value, $\left.1.3 \times 10^{-5}\right)$. Furthermore, the residues 16 to 442 were aligned to the tail sheath protein encoded by gene $d s y 3957$ from the prophage of Desulfitobacterium hafniense (PDB ref $3 \mathrm{HXL}$ ) with a probability of 98.5 (E-value, $6.3 \times 10^{-6}$ ).

The best 3D model of the full-length gp053 predicted using the I-TASSER server (Figure 1) showed a C-score of -1.77 and a TM-score of $0.50 \pm 0.15$. The top three proteins from the PDB that had the closest structural similarity to the predicted model were 3LML, 3HXL and 6GKW with a TM-score of $0.801,0.659$ and 0.602 , respectively.

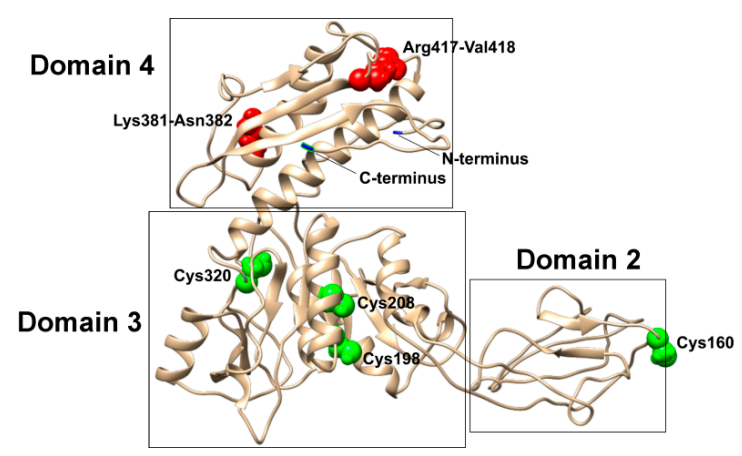

Figure 1. A model of gp053 generated by I-TASSER. The locations of the $\mathrm{N}$ and $\mathrm{C}$ termini are shown in blue; Cys160, Cys196, Cys208 and Cys320 are shown in green; Lys381-Asn382 and Arg417-Val418 are shown in red. The domain numbering was done according to Kurochkina et al. [38]. The model was visualised using UCSF Chimera. 


\subsection{Production and Analysis of the Recombinant gp053}

Initially, for gene 053 expression in E. coli cells, three plasmids encoding wild-type, N- and C-His-tagged gp053 were designed (Supplementary Table S2). The soluble recombinant gp053 with a molecular mass of $\sim 50 \mathrm{kDa}$ (predicted mass - $50.245 \mathrm{kDa}$ ) was produced after induction with IPTG and incubation at $30{ }^{\circ} \mathrm{C}$ for three hours. The TEM analysis of the cell-free extracts revealed that the overexpressed gp053 self-assembled into regular tubular structures-polysheaths (Figure 2C). The width of the gp053 polysheaths $(27.13 \pm 2.69 \mathrm{~nm})$ corresponded to the width of the contracted tail $(26.79 \pm 1.78 \mathrm{~nm})$ of the phage FV3 [44]. The length of the polysheaths varied from separate rings with an internal hole of $11.51 \pm 0.78 \mathrm{~nm}$ and a diameter of $27.83 \pm 2.68 \mathrm{~nm}$ to nanotubes up to $1000 \mathrm{~nm}$ long. The attempts to purify long ordered His-tagged gp053 polysheaths effectively by using the metal-chelating sorbent were unsuccessful (Figure 2). The SDS-PAGE analysis revealed that the vast majority of the recombinant proteins did not adsorb onto the sorbent. Moreover, according to the results of the TEM analysis, the affinity-purified recombinant gp053 formed noticeably shorter tubular structures (Figure 2D,E).

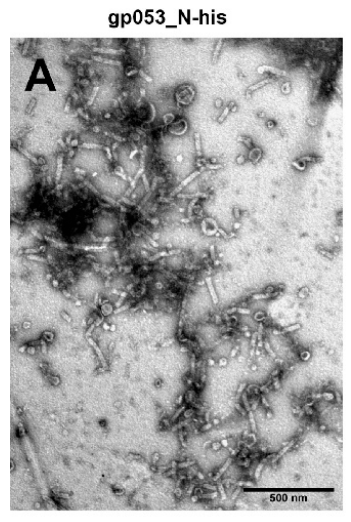

gp053_N-his

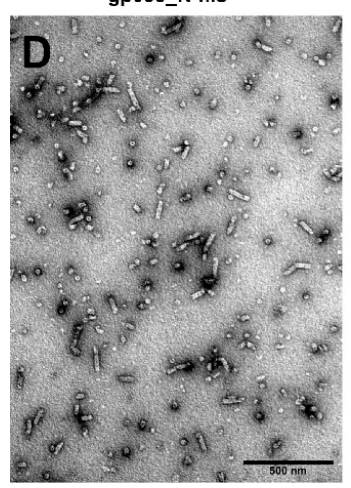

gp053_C-his

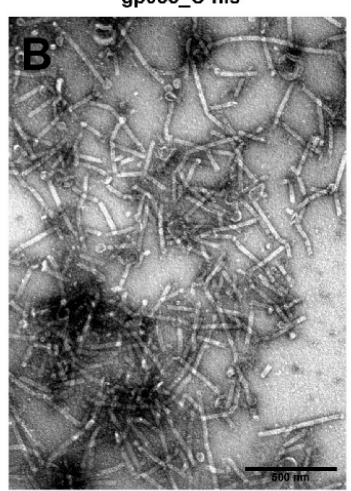

gp053_C-his

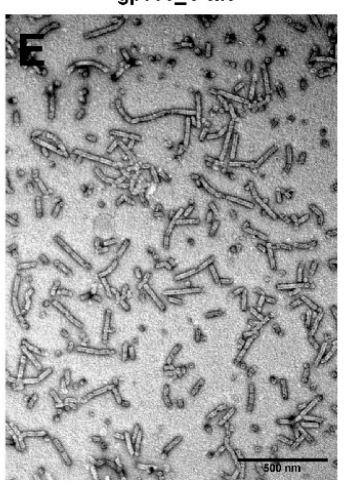

gp053

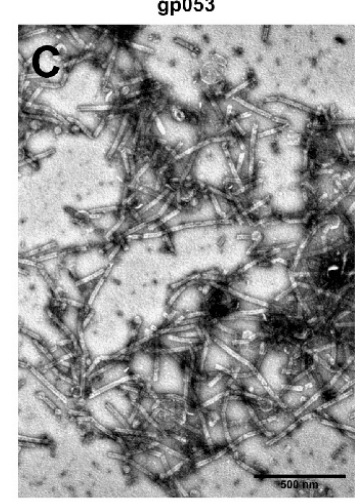

gp053

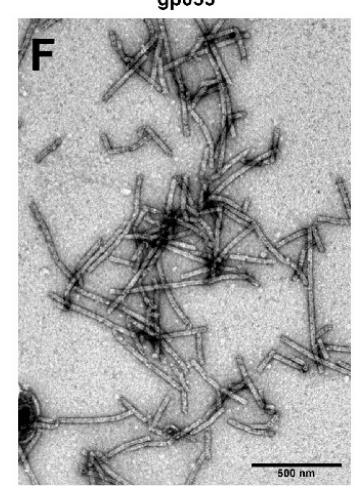

Figure 2. TEM analysis of polysheaths formed by recombinant gp053. The electron micrographs represent the structures before (above) and after (below) purification from the crude cell lysates. The polysheaths formed by recombinant gp053_N-his (A,D) and gp053_C-his (B,E) were purified using the His-Spin Protein Miniprep kit (Zymo Research) according to the manufacturer's recommendations. The polysheaths, formed by recombinant gp053 (C,F) were purified by precipitation using ammonium sulphate (10\% final concentration).

Alternatively, we have demonstrated that the purification of the polysheaths could be performed quickly and effectively by using ammonium sulphate precipitation (Figures $2 \mathrm{~F}$ and 3 ). The yield of the bacteria-derived and purified structures was $3.75 \pm 0.35 \mathrm{mg} / \mathrm{g}$ of wet cells. The TEM analysis of the purified protein showed that the morphology of the polysheaths (Figure 3B) corresponded to the morphology of the tubular structures observed in the cell-free extracts. 


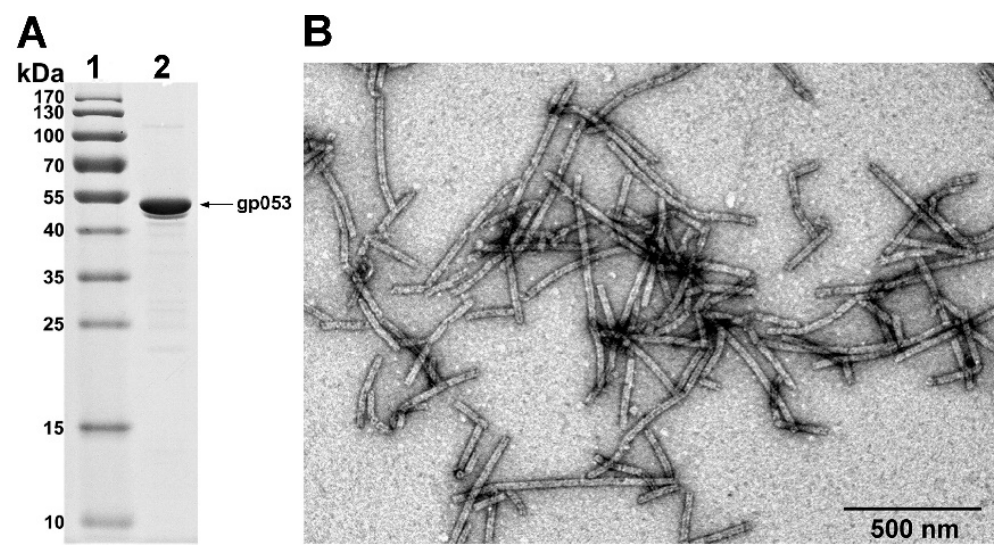

Figure 3. SDS-PAGE (A) and TEM (B) analysis of the purified wild-type recombinant gp053 produced in E. coli BL21 (DE3) cells. Protein synthesis was induced by $0.1 \mathrm{mM}$ IPTG and the cells were incubated at $30{ }^{\circ} \mathrm{C}$ for $3 \mathrm{~h}$. The recombinant gp053 was precipitated from the supernatant by the addition of ammonium sulphate to a final concentration of $10 \%$. Lanes: 1 -the molecular mass marker, Page Ruler $^{\mathrm{TM}}$ prestained Protein Ladder Plus (Thermo Fisher Scientific, Vilnius, Lithuania); 2-the purified wild-type recombinant gp053.

The purified polysheaths exhibited extraordinary stability. The structures withstood overnight incubation in $8 \mathrm{M}$ urea. Moreover, even boiling them for $30 \mathrm{~min}$ or prolonged storage (more than one year) in TE buffer at $4{ }^{\circ} \mathrm{C}$ did not affect the morphology of the gp053 polysheaths (Figure 4C,E,F). Also, the polysheaths remained as ordered tubular structures after incubation with trypsin (Figure 4D).
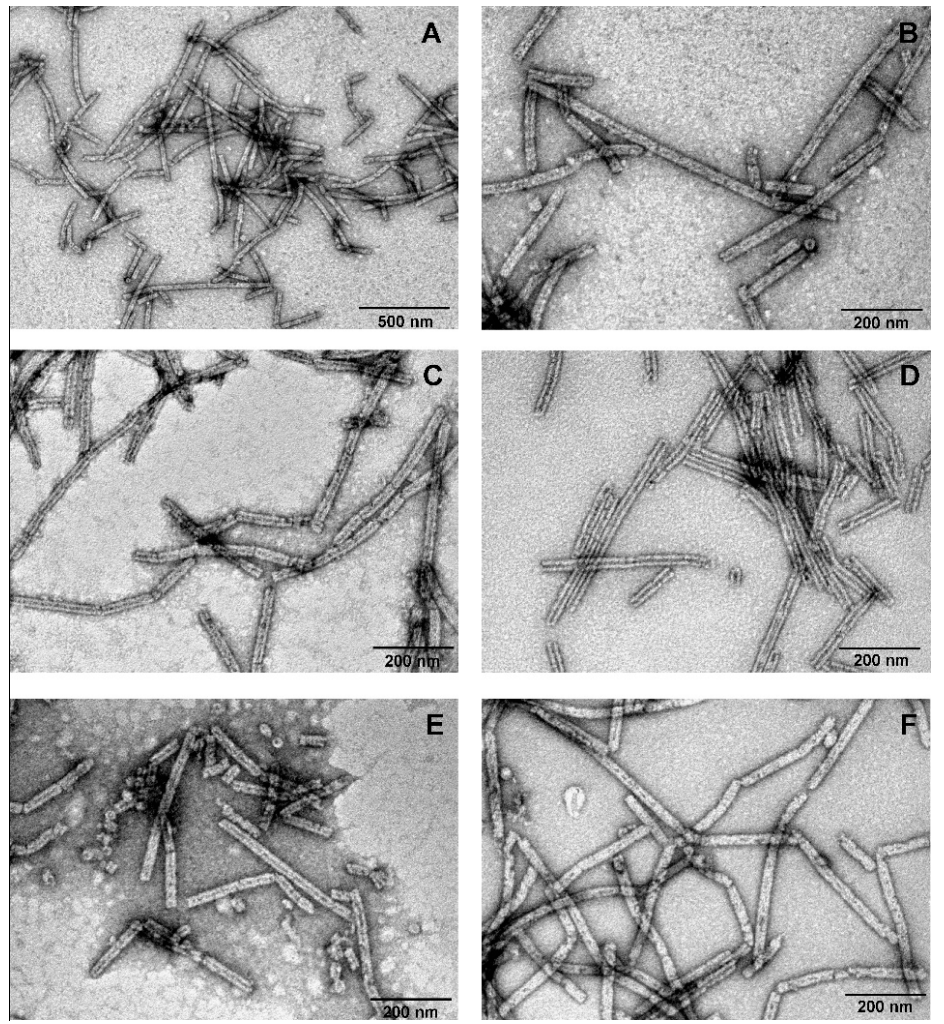

Figure 4. Electron micrographs of the polysheaths formed by wild-type recombinant gp053 from phage FV3. The samples of the purified polysheaths were analysed immediately after purification (A,B), following storage in TE buffer at $4{ }^{\circ} \mathrm{C}$ for 12 months (C), after treatment with trypsin $(0.02 \mathrm{mg} / \mathrm{mL})$ at $22{ }^{\circ} \mathrm{C}$ for $16 \mathrm{~h}(\mathbf{D})$, after incubation in the presence of $8 \mathrm{M}$ urea at $22^{\circ} \mathrm{C}$ for $16 \mathrm{~h}(\mathbf{E})$, and after incubation in boiling water for $30 \mathrm{~min}(\mathbf{F})$. 
The detailed analysis of the trypsin-treated protein tubes by SDS-PAGE showed that fragments with molecular masses of approximately 43,39 and $37 \mathrm{kDa}$ appeared in addition to the full-length gp053 (Figure 5). Based on these results, it was concluded that only several trypsin digestion sites out of the 22 existing in the gp053 protein were available on the surface of the polysheaths. To identify those sites, the protein bands were excised from the gel before and after proteolysis by trypsin, purified according to the protocol described by Hellman et al. [46], and liquid chromatography coupled with mass spectrometry (LC-MS/MS) was performed. The protein sequence coverage map was obtained from the ProteinLynx Global Server (PLGS) processed $\mathrm{MS}^{\mathrm{E}}$ data (three technical replicates) (Supplementary Figure S2). The results of the qualitative and quantitative MS analysis of the peptides showed that the vast majority of the proteins in the suspension of the purified polysheaths consisted of the potential full-length gp053 (Figure 5B, lane 1, arrow 1), whereas a minor protein band (Figure 5B, lane 1, arrow 2) contained gp053 with a potential $86 \mathrm{~N}$-terminal amino acid truncation. This truncated protein was expected to occur due to the proteolytic activity of some of the proteases from the E. coli cells, since the protease inhibitors were not added during the purification of the polysheaths. After treatment with trypsin, the most intensive protein bands were identified as potentially full-length gp053 (Figure 5B, lane 2, arrow 3), gp053 with the C-terminal truncation of 41 amino acids (Figure 5B, lane 2, arrow 4) and gp053 with the C-terminal truncation of 77 amino acids (Figure 5B, lane 2, arrow 5). The minor protein band consisted of the gp053 with potential truncations of $86 \mathrm{~N}$-terminal and $77 \mathrm{C}$-terminal amino acids (Figure 5B, lane 2, arrow 6).
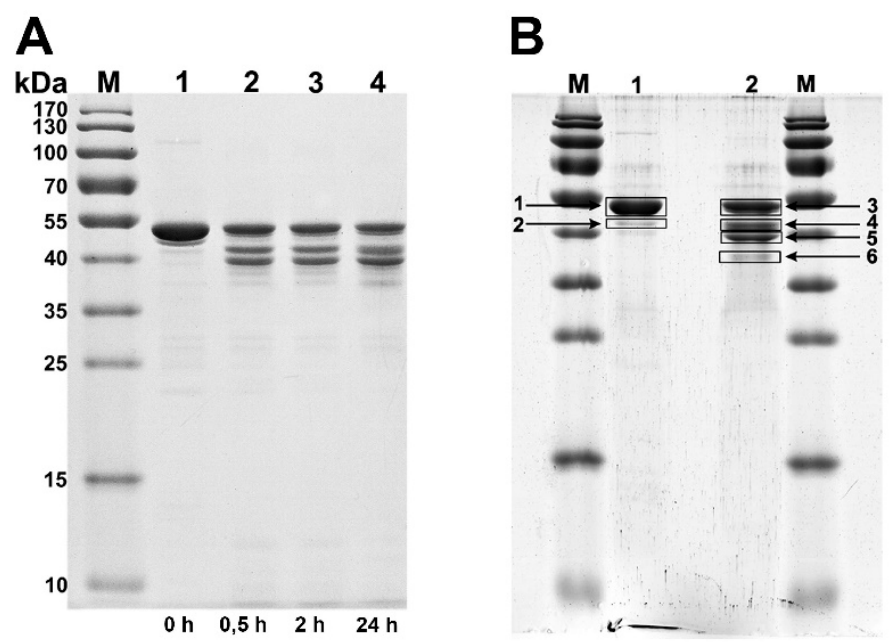

Figure 5. SDS-PAGE analysis of the trypsinisation products of the purified gp053 polysheaths. (A) Lanes: $\mathrm{M}$-molecular mass marker, Page Ruler ${ }^{\mathrm{TM}}$ Prestained Protein Ladder (Thermofisher), 1-recombinant gp053, 2-4 recombinant gp053 incubated with trypsin (the digestion time is indicated under the lanes). (B) Lanes: M-molecular mass marker, Page Ruler ${ }^{\mathrm{TM}}$ Prestained Protein Ladder (Thermofisher); 1-recombinant gp053 incubated for 24 hours in TE buffer; 2-recombinant gp053 incubated for 24 hours in TE buffer with trypsin. The arrows indicate the full-length gp053 $(1,3)$ and its fragments (2,4-6), excised from the gel for LC-MS/MS analysis.

According to this analysis, trypsin digestion of gp053 proceeded in a specific manner and resulted in the potential cleavage of the peptide bond between Lys381-Asn382 and Arg417-Val418 (Figure 1).

\subsection{Construction of gp053 Mutants}

In order to obtain truncated recombinant proteins still able to form regular, stable tubular structures and to understand the polymerisation properties of gp053, we constructed a set of the gp053 mutants truncated at the $\mathrm{N}$ or/and $\mathrm{C}$ terminus. Those recombinant proteins corresponded to the full-length gp053 from 98.0\% (gp053_N $\Delta 9$ ) to 43.7\% (gp053_C $\Delta 200$ ) (Supplementary Table S2, Figure 6). 


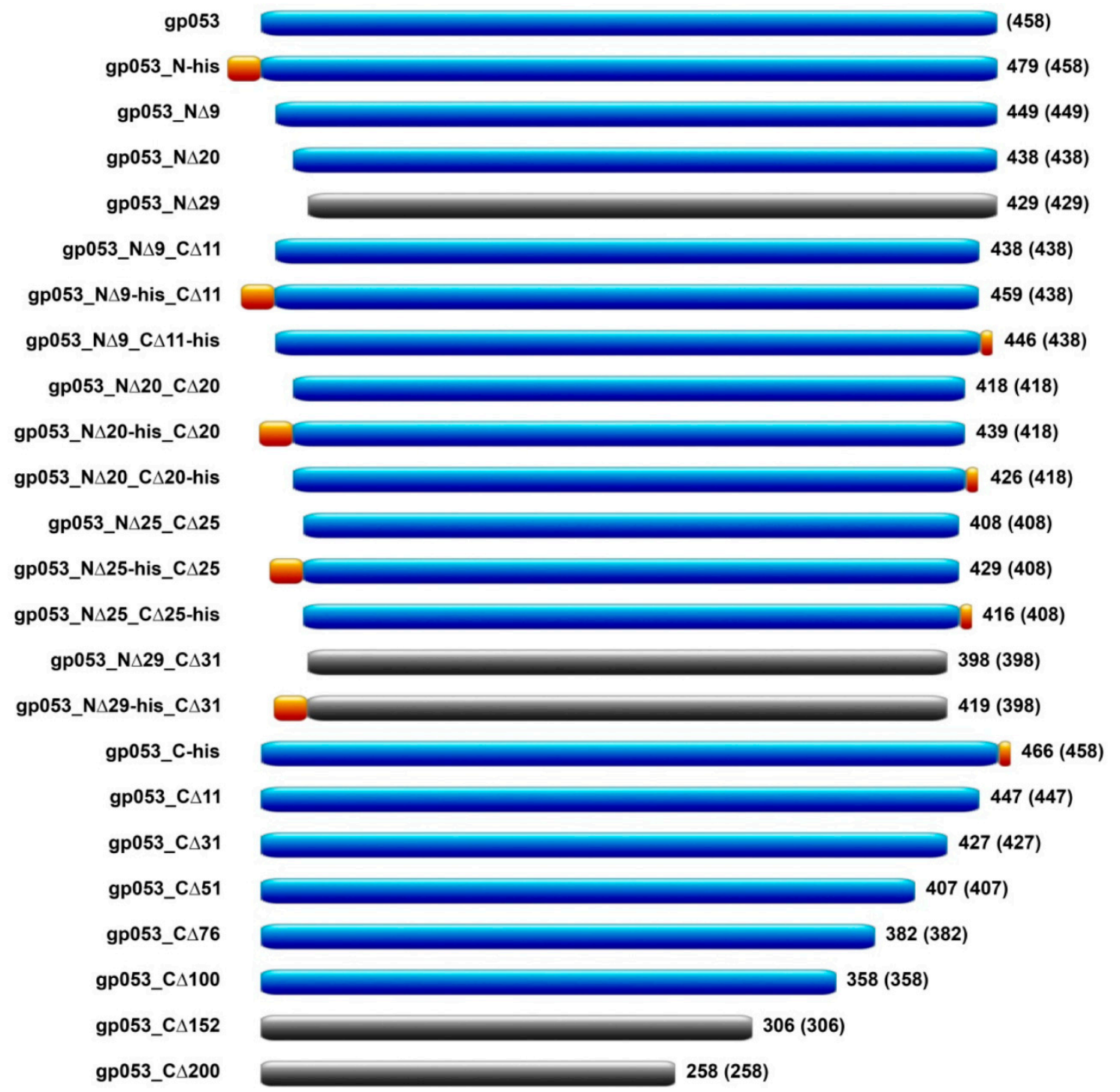

Figure 6. A schematic picture of the truncated mutants of the gp053 protein. The mutants are named (shown on the left) according to $\mathrm{N}$-terminal or C-terminal mutations and the presence of His-tag. The proteins, able to polymerise into nanotubes, are shown in blue. The mutants, incapable of polymerisation, are shown in black. The His-tags are shown in orange. The size of a protein in amino acids is shown on the right, and the portion of wild-type gp053 within a construct is depicted in parenthesis.

The recombinant proteins were produced in E. coli BL21 (DE3) cells and the cell-free extracts were analysed by TEM. Whenever an assembly into the polysheaths was observed, the purification procedures using ammonium sulphate were performed. The TEM analysis revealed that deletions of 9, 20 and 25 amino acids from the N-terminal region did not disturb the protein assembly into polysheaths. Meanwhile, a deletion of 29 amino acids from the N-terminal region abolished the ability of the truncated gp053 to assemble into the typical polysheaths. Therefore, the gp053_N $\Delta 29$ was found in a soluble fraction, where it was folded into the unordered protein ribbons (Supplementary Table S2, Figure 6). On the other hand, the deletions of 11, 31, 51, 76 and even 100 amino acids from the $\mathrm{C}$ terminus did not abolish the formation of the ordered tubular polysheaths. However, the gp053_C $\Delta 150$ mutant lacking 152 amino acids at the $C$ terminus formed insoluble aggregates in E. coli cells (Supplementary Table S2, Figure 6). 
The TEM analysis of the polysheaths formed by the majority of the mutants, except for gp053_N-his and gp053_C $\Delta 100$, revealed that the structures showed no significant differences compared to the polysheaths formed by the wild-type recombinant gp053 (Supplementary Table S2, Figure 7).

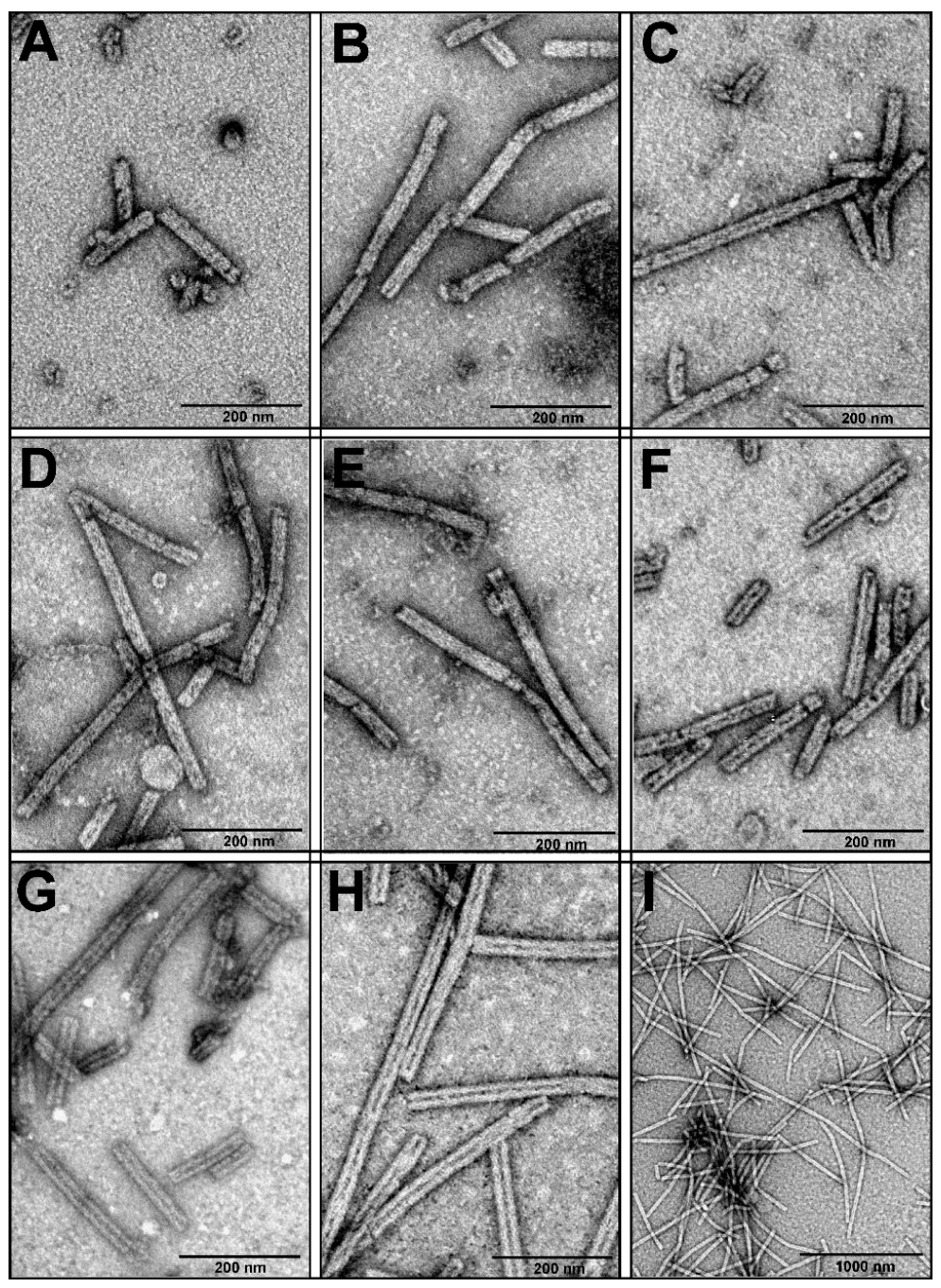

Figure 7. Electron micrographs of the polysheaths formed by the gp053 mutants. (A) gp053_N-his, (B) gp053_C-his, (C) gp053_N $\Delta 9$ _C $\Delta 11$, (D) gp053_N $\Delta 9$-his_C $\Delta 11$, (E) gp053_N $\Delta 25-h i s \_C \Delta 25$, (F) gp053_N $\Delta 20,(\mathbf{G})$ gp053_C $\Delta 76$, and $(\mathbf{H}, \mathbf{I})$ gp053_C $\Delta 100$.

On the contrary, the polysheaths formed by the gp053_N-his mutant were less ordered and approximately 2-5-fold shorter in length ( 100-300 nm) (Figure 7A). In the case of the gp053_C $\Delta 100$, the tubular structures were longer (up to $\sim 3000 \mathrm{~nm}$ ) and slightly larger in diameter $(\sim 32.47 \mathrm{~nm}$ ) (Figure 7H,I) compared to the wild-type ones. In addition, it was observed that some of the nanotubes, for example, formed by gp053_N $\Delta 20$, gp053_C $\Delta 76$ and gp053_C $\Delta 100$ (Figure 7F-H, respectively), contained more clearly defined internal channels. A similar morphology was also detected in the case of the full-length gp053 after prolonged storage in TE buffer or treatment with trypsin (Figure 4C,D, respectively).

\subsection{Investigation of the Oligomeric Constructs of gp053}

According to the 6-start helix symmetry of the polysheath, the gp053 oligomers were genetically engineered (Supplementary Table S2, Figure 8A) and their ability to form the ordered structures was analysed. Initially, it was found that all the recombinant proteins (gp053_N_C_mon, gp053_N_C_dim, 
gp053_N_C_trim, gp053_N_C_tet, gp053_N_C_pent and gp053_N_C_hex) were soluble under the investigated conditions (Figure 8C).
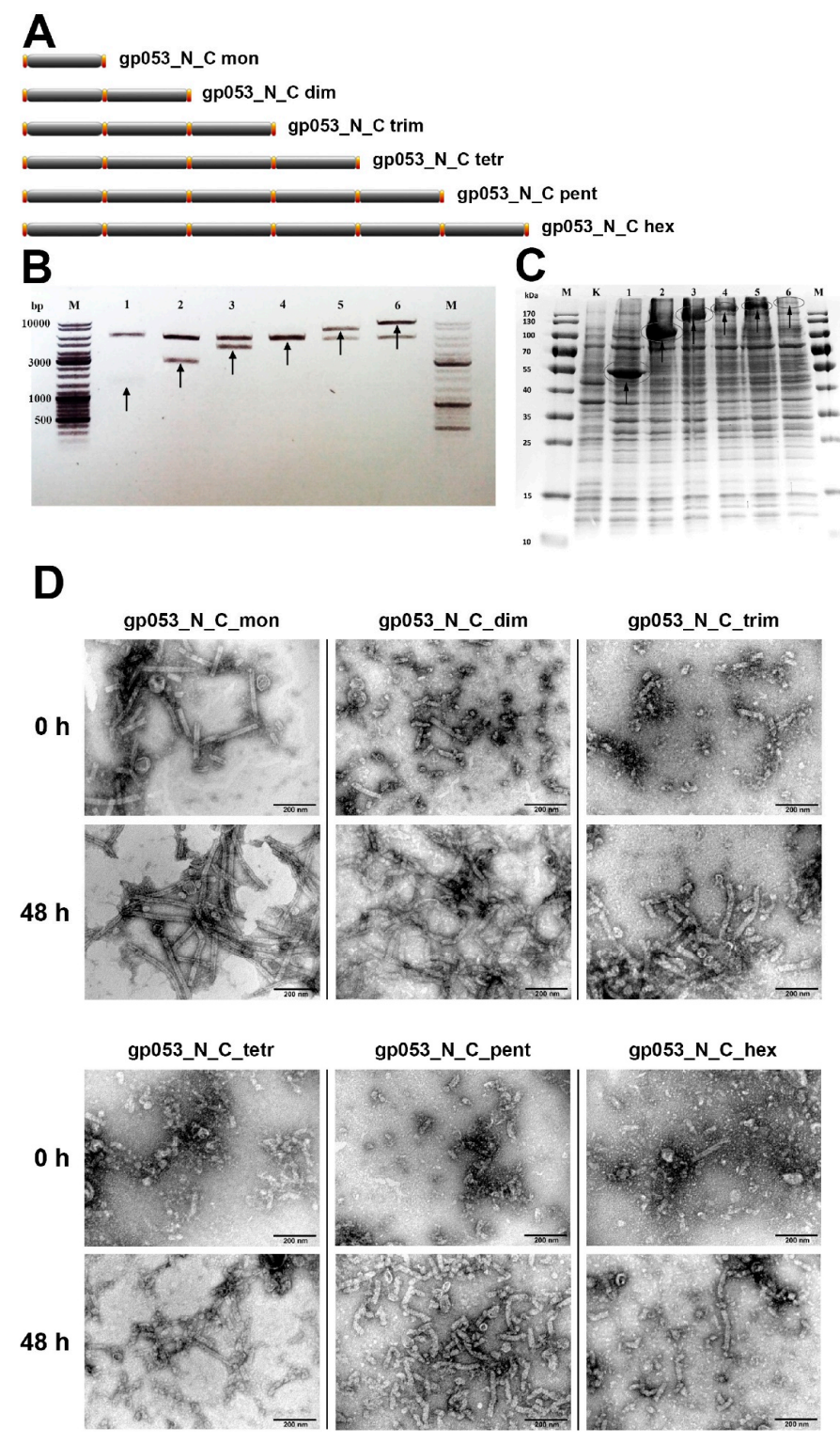

Figure 8. Assembling of the gp053 oligomers. (A) A schematic representation of the gp053 oligomeric constructs. The amino acids of the wild-type gp053 within the construct are shown in black, and the insertions with cloning sites are shown in orange. The constructs are named according to the number of copies of the gene 053. (B) The agarose gel electrophoresis analysis of plasmids harbouring the fused 053 genes. The arrows indicate DNA fragments encoding gp053 after hydrolysis with NdeI and XhoI. Lanes: M-molecular mass marker, GeneRuler ${ }^{\mathrm{TM}}$ DNA Ladder Mix (Thermo Fisher Scientific, Vilnius, Lithuania); 1-gp053_N_C_mon; 2-gp053_N_C_dim; 3-gp053_N_C_trim; 4-gp053_N_C_tetr; 5-gp053_N_C_pent; and 6-gp053_N_C_hex. (C) The SDS-PAGE analysis of the cell-free extracts of the E. coli BL21 (DE3) cells producing the recombinant gp053 oligomers. Lanes: $\mathrm{M}-$ molecular mass marker, Page Ruler ${ }^{\mathrm{TM}}$ prestained Protein Ladder Plus (Thermo Fisher Scientific, Vilnius, Lithuania); K-pET21a (plasmid vector, control); 1-gp053_N_C_mon; 2-gp053_N_C_dim; 3-gp053_N_C_trim; 4-gp053_N_C_tetr; 5-gp053_N_C_pent; and 6-gp053_N_C_hex. (D) The TEM analysis of the structures formed by the recombinant gp053 oligomers. The cell-free extracts were analysed immediately after cell disruption and sample preparation or after incubation with periodical shaking at $22{ }^{\circ} \mathrm{C}$. The incubation time is indicated on the left. 
When the samples were analysed by TEM immediately after the disruption of cells, the ordered tubular structures up to $\sim 400 \mathrm{~nm}$ in length were visible only in the case of the monomeric gp053. Some tubular structures up to $\sim 200 \mathrm{~nm}$ in length were also visible in the case of the dimeric gp053. The other oligomers of gp053 formed indefinite structures (Figure 8D). However, the tubular structures, although of a less regular structure, were observed in the case of all oligomers after an incubation of the samples in TE buffer with periodic shaking at $22{ }^{\circ} \mathrm{C}$ for $48 \mathrm{~h}$ (Figure 8D).

\subsection{Labelling of gp053 Polysheaths with Neutravidin-Conjugated Gold Nanoparticles}

Based on the model of the structure of gp053, one of the four cysteines, Cys160, was located on putative domain 2 (Figure 1), which was found on the outer surface of the polysheaths formed by LIN1278, DSY3957 and gp18 [38]. In order to determine whether this amino acid was on the surface of the nanotubes formed by recombinant gp053, the purified polysheaths were modified with biotin and incubated with neutravidin-conjugated gold nanoparticles. The TEM analysis revealed that the gold nanoparticles in most cases were visible on the ends or breakpoints of the polysheaths, single rings or short gp053 aggregates, and the rest of the outer surface of the protein nanotubes was not decorated with gold nanoparticles (Figure 9B).
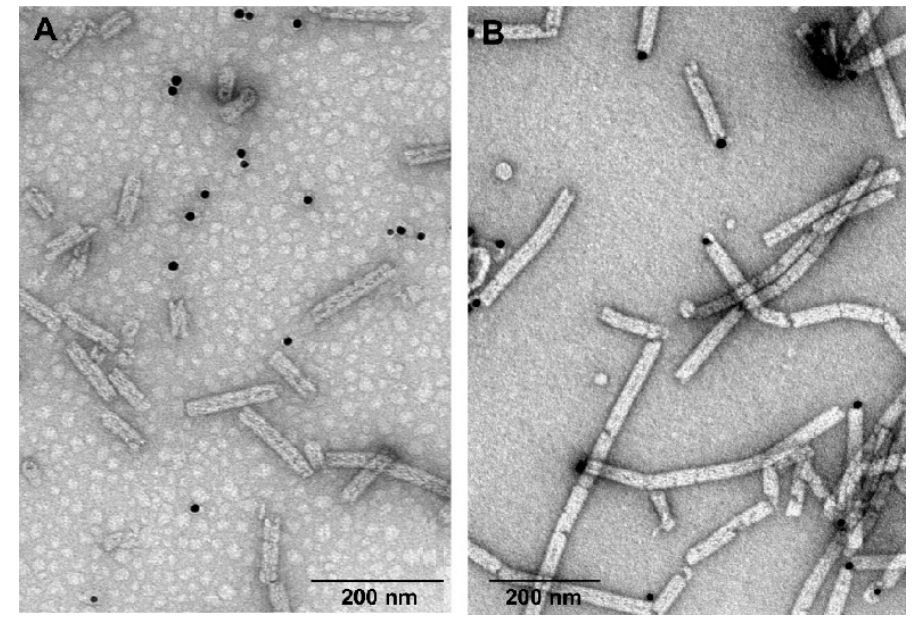

Figure 9. Electron micrographs of the polysheaths formed by the purified recombinant gp053 incubated with the neutravidin-conjugated gold nanoparticles. (A) Non-modified gp053, and (B) gp053-harbouring cysteines modified with biotin.

Thus, we can conclude that the cysteine residues of gp053 were buried inside of the protein nanotubes, and only could be accessible for labelling with neutravidin-conjugated gold nanoparticles at the termini of the polysheaths.

\section{Discussion}

The construction of various nanostructures based on self-assembling biomolecules is currently of special interest due to the potential for diverse application in different fields of nanobiosciences. However, only a limited number of self-assembling proteins from bacteriophages have been studied in detail to date. Therefore, in this study, we aimed to shed more light on the diversity of self-assembling tubular nanostructures and chose to investigate the tail sheath protein (gp053) from enterobacteria phage vB_EcoM_FV3.

Despite 98-99\% sequence identity of the tail sheath proteins from phages of the genus V5virus, the molecular architecture of FV3 gp053 is largely undetermined. To our knowledge, none of the crystal structures of the tail sheath proteins from the genus V5virus or their close relatives have been resolved to date. On the other hand, it has been reported that the structure of the domains constituting the tail sheath proteins from phages $\mathrm{T} 4$, phiKZ, and phi812 are similar despite lower than 
$15 \%$ sequence identity between the aforementioned proteins $[29,60,61]$. It has also been shown that contractile structures from phages have very similar architecture to contractile molecular machines found in many prokaryotes: R-type pyocins, the Type VI secretion system (T6SS) and phage tail-like protein translocation structures (PLTS) [32,62-65]. Moreover, phylogenetic analysis of the tail sheath proteins DSY3957 (PDB ref: 3HXL) and LIN1728 (PDB ref: 3LML) from the prophages revealed that, phylogenetically, they are more closely related to the R-type pyocin from Clostridium difficile, than to the tail sheath proteins from other phages [63]. Therefore, it is unsurprising that the HHpred analysis showed the predicted fold of gp053 from phage FV3 to be more similar to the R-type pyocins from Clostridium difficile (PDB ref 6GKW) and Pseudomonas aeruginosa (PDB ref 3J9Q) than to the fold of the tail sheath proteins from prophages (PDB ref 3LML, PDB ref 3HXL) or phages (PDB ref 5LI4, PDB ref 3J2M). On the other hand, bioinformatics analysis revealed that the gp053 identity compared to the previously mentioned proteins at the amino acid level ranged only from $14.6 \%$ (3HXL) to $18.8 \%$ (6GKW). Therefore, it has been demonstrated that despite the fact that the tail sheath proteins of different Myoviridae phages appeared to have similar helical parameters and functioned in a similar manner $[29,31,32,38,66-70]$, completely different sequences of amino acids forming the tail sheath proteins could exist.

Here, we demonstrated that it was possible to obtain comparatively high amounts of recombinant gp053 protein quickly and efficiently through the use of E. coli expression systems. It has been shown that recombinant gp053 formed soluble high molecular weight polysheaths during production in the E. coli cells, and the purification of these nanostructures could be performed very quickly, cheaply and efficiently using an ammonium sulphate precipitation from the cell-free extracts only (Figure 2). In contrast, the precipitation of the polysheaths of phage PaBG by using ammonium sulphate was not as effective. Therefore, additional fractionation by ultracentrifugation was needed [71]. Additional purification procedures, including ultracentrifugation, hydroxyapatite and anion-exchange chromatography, have been used to purify nanostructures formed by the recombinant tail sheath proteins of phages T4 and phiKZ [38,42].

Another important characteristic of the polysheaths formed by gp053 is their extreme stability towards various physical and chemical treatments. Similarly, the polysheaths consisting of the tail sheath proteins of other phages have also been shown to be very stable structures. It has been demonstrated that the polysheaths of phage $\mathrm{T} 4$ retained their structure after incubation in $8 \mathrm{M}$ urea ( $\mathrm{pH}$ 7.6-12.2), $6 \mathrm{M}$ guanidine hydrochloride ( $\mathrm{pH}$ 5.6) and 7.8 $\mathrm{M}$ acetic acid ( $\mathrm{pH}$ 1.8-6.1) [39]. Moreover, the polysheaths of phages $\mathrm{T} 4$ and phiKZ were also found to be extremely resistant to proteolysis by trypsin $[38,41]$. However, although the polysheaths of phage phiKZ remained uncrumbled after incubation with trypsin, the protein was completely cleaved into two fragments, as indicated by the disappearance of the full-length protein band and the appearance of two smaller fragments with molecular masses of about 60 and $15 \mathrm{kDa}$ [38]. In contrast, a significant amount of the recombinant gp053 from phage FV3 remained undigested even after 24 hours of incubation with trypsin (Figure 5). It is likely that different trypsinisation profiles can be concerned with the morphological differences of polysheaths of the previously mentioned phages. In the case of the recombinant tail sheath protein of phage phiKZ, polysheaths with more visible internal channels have been observed. It has been suggested that these structures were caused by less compact packing of protein subunits that facilitates stain penetration into the internal channel of the polysheaths [38]. Meanwhile, the polysheaths composed of recombinant gp053 were different. It is possible that these structures are formed of highly compact protein subunits which are difficult for trypsin to reach. On the other hand, polysheaths with a better defined internal channel were observed in the cases of gp053 mutants such as gp053_N $\Delta 20$, gp053_C $\Delta 76$ and gp053_C $\Delta 100$ as well as a full-length gp053 after prolonged storage in TE buffer or after treatment with trypsin (Figures 4 and 7). Therefore, it is likely that less compact structures were formed in these cases.

LC-MS ${ }^{\mathrm{E}}$ analysis of the trypsinisation products of the recombinant wild-type gp053 of FV3 revealed the potential trypsin-accessible cleavage sites between Lys381-Asn382 and Arg417-Val418 
(Supplementary Figure S2). Based on the I-TASSER generated model of gp053, Lys381-Asn382 and Arg417-Val418, together with its N and C termini, are found in domain IV (Figure 1), which is structurally similar to the domains of the prophage tail sheath proteins DSY3957 and LIN1278, which have the same fold as the corresponding region (domain IV) of bacteriophage T4 [38]. It was demonstrated that the $\mathrm{N}$ and $\mathrm{C}$ termini of the tail sheath proteins are found close to each other and form a domain, which is located in the inner part of the contracted sheath [29-32,38]. Thus, with reference to the conserved structural model of the tail sheath proteins of bacteriophages and contractile molecular machines found in prokaryotes [65], it is the most likely that the $\mathrm{N}$ and $\mathrm{C}$ termini, as well as Lys381-Asn382 and Arg417-Val418, are located in the inner part of the polysheaths formed by gp053 of FV3. The results of the purification procedures of recombinant gp053 maintained these speculations-attempts to purify long tubular His-tagged gp053 polysheaths effectively by using the metal-chelating sorbent were unsuccessful (Figure 2).

The results of the experiments with FV3 gp053 deletion mutants were in accordance with previous observations that the elimination of the C-terminal residues of tail sheath proteins (gp18) from phage T4 had a less negative effect on the polymerisation properties, compared to deletions of the $\mathrm{N}$ terminus $[42,43,72]$. On the other hand, it has been demonstrated that some T4 gp18 mutants assembled into thinner filaments called "noncontracted polysheaths" (NCPs) [42], which might correspond to the transitional helices described previously [73]. However, NCPs in the case of gp053 mutants were not observed. In contrast, it has been demonstrated that the tubular structures, formed by gp053_C $\Delta 100$, were even longer and of a larger diameter than the polysheaths formed by wild-type recombinant gp053 (Figure 7).

In this study, for the first time, to our knowledge, the genetically engineered homooligomers of the tail sheath proteins from bacteriophages have been constructed. It was demonstrated that all of the recombinant gp053 duplicates were soluble under the investigated conditions. Moreover, a self-assembling process of a number of these proteins in vitro, in the absence of other viral proteins, was observed (Figure 8). Hence, the tubular, although irregular structures, were visible not only in the case of recombinant gp053 monomer (gp053_N_C_mon) but also and in the cases of other gp053 oligomers including gp053 pentamer (gp053_N_C_pent). These results are not only promising for the construction of self-assembling nanostructures with various materials exhibited in specific locations on their surfaces but they also raise a number of issues about the polymerisation processes of the tail sheath proteins of bacteriophages.

The I-TASSER-generated model of gp053 (Figure 1) showed that one out of four cysteine residues found in gp053, Cys160, was located in the predicted domain 2, which was structurally similar to the protruding domains forming the outer surface of contractile tail machines [29-32,38]. On the other hand, the results of the labelling of gp053 polysheaths with neutravidin-conjugated gold nanoparticles revealed that maleimide-based biotinylation occurred only at the termini of the polysheaths and none of the four cysteine residues (including Cys160) were located on the outer surface of the polysheaths freely available for biotinylation (Figure 9). Despite the fact that the specific cysteine residue (or several of them) that was biotinylated within gp053 is still unknown, a simple method to adhere gold nanoparticles to the termini of the polysheaths was shown. The attachment of gold nanoparticles could be very beneficial for the immobilisation of uniformly oriented nanostructures [74]. Thus, the results of this study suggest novel ways to construct hybrid self-assembling nanostructures, particularly ones appropriately prearranged on surfaces.

It has been demonstrated that self-assembling tubular nanostructures made of peptides, proteins or filamentous bacteriophages have been used for both fundamental studies and practical applications, including in the construction of biosensors, energy storage devices, drug delivery systems or tissue engineering $[12-14,75,76]$. Given the fact that the polysheaths, formed of the wild-type gp053 or its mutants, possess physicochemical properties which are very similar to the properties of self-assembling nanostructures formed of biomolecules mentioned above (well-defined shape and dimensions in the nanoscale, robust, ordered and intrinsically monodisperse structures), it is likely that gp053 polysheaths 
can be used for the same practical applications as tubular nanostructures made of peptides, proteins or filamentous bacteriophages. For example, the gp053 polysheaths, which are up to $1000 \mathrm{~nm}$ in length, $\sim 28 \mathrm{~nm}$ in diameter and with an internal hole of $\sim 12 \mathrm{~nm}$, are very attractive tools for the synthesis of inorganic matter to produce nanowires with properties of interest to energy sciences and the electronic industry. Polysheaths can potentially be used for mineralisation, both in their interior channel and around their exterior surface as has been demonstrated in the case of the tobacco mosaic virus $[77,78]$. On the other hand, the polymerisation of recombinant tail sheath proteins is not a precisely controlled process and this still remains the main drawback associated with these nanostructures, hence additional studies are needed to tackle this issue.

Nevertheless, the production and purification of polysheaths, formed from recombinant gp053, is a relatively short, simple and cheap process: only after three hours following induction and after a few hours of purification procedures, it is possible to produce a high yield of purified nanostructures. In contrast, the in vivo or in vivo/in vitro propagation of phage M13 and plant viruses takes several days or several weeks, respectively [79-81]. In addition, the polysheaths are released from bacteria by cell lysis, thus, these structures are not strictly limited in either the size of the displayed (poly)peptides or in terms of the hydrophobicity of the polypeptide chain, which was demonstrated as a serious limitation of nascent rod-shaped virions to passage through the host's exit pore [81].

To summarise, gp053 from phage FV3 self-assembles into ordered tubular structures-polysheaths. The assembly proceeds in vivo and in the absence of other viral proteins. Polysheaths formed of the wild-type gp053 or its mutants possess physicochemical properties which are very attractive for the construction of self-assembling nanostructures with potential applications in different fields of nanosciences.

Supplementary Materials: The following are available online at http:/ /www.mdpi.com/1999-4915/11/1/50/s1, Table S1: Oligonucleotides used in this study; Table S2: Constructs of gp053; Table S3: Homology of gp053 from FV3 with proteins from other bacteriophages; Figure S1: Schematic representation of construction of gp053 oligomers; Figure S2: The protein sequence coverage map obtained from the PLGS-processed $\mathrm{MS}^{\mathrm{E}}$ data.

Author Contributions: R.M., L.T. and E.Š. conceived and designed the experiments; E.Š., L.T., R.R., S.P., K.G. and A.K. performed the experiments; R.M., E.Š. and A.K. analysed the data; R.M. and M.V. contributed reagents/materials/analysis tools; E.Š. and R.M. wrote the paper.

Funding: This research was funded by the European Union's Horizon 2020 research and innovation program [BlueGrowth: Unlocking the potential of Seas and Oceans] under grant agreement No. 634486 (project acronym INMARE).

Conflicts of Interest: The authors declare no conflict of interest.

\section{References}

1. Busseron, E.; Ruff, Y.; Moulin, E.; Giuseppone, N. Supramolecular self-assemblies as functional nanomaterials. Nanoscale 2013, 5, 7098-7140. [CrossRef] [PubMed]

2. Li, F.; Wang, Q. Fabrication of nanoarchitectures templated by virus-based nanoparticles: Strategies and applications. Small 2014, 10, 230-245. [CrossRef]

3. Lee, E.J.; Lee, N.K.; Kim, I.S. Bioengineered protein-based nanocage for drug delivery. Adv. Drug Deliv. Rev. 2016, 106, 157-171. [CrossRef] [PubMed]

4. Yokoi, N.; Inaba, H.; Terauchi, M.; Stieg, A.Z.; Sanghamitra, N.J.; Koshiyama, T.; Yutani, K.; Kanamaru, S.; Arisaka, F.; Hikage, T.; et al. Construction of robust bio-nanotubes using the controlled self-assembly of component proteins of bacteriophage T4. Small 2010, 6, 1873-1879. [CrossRef] [PubMed]

5. Zhou, J.C.; Soto, C.M.; Chen, M.S.; Bruckman, M.A.; Moore, M.H.; Barry, E.; Ratna, B.R.; Pehrsson, P.E.; Spies, B.R.; Confer, T.S. Biotemplating rod-like viruses for the synthesis of copper nanorods and nanowires. J. Nanobiotechnol. 2012, 10, 18. [CrossRef]

6. Drygin, Y.; Kondakova, O.; Atabekov, J. Production of platinum atom nanoclusters at one end of helical plant viruses. Adv. Virol. 2013, 2013, 746796. [CrossRef]

7. Swaminathan, S.; Cui, Y. Biochemical functionalization of peptide nanotubes with phage displayed peptides. Nanotechnology 2016, 27, 365703. [CrossRef] 
8. Huang, Y.; Chiang, C.Y.; Lee, S.K.; Gao, Y.; Hu, E.L.; de Yoreo, J.; Belcher, A.M. Programmable assembly of nanoarchitectures using genetically engineered viruses. Nano Lett. 2005, 5, 1429-1434. [CrossRef]

9. Singh, P.; Gonzalez, M.J.; Manchester, M. Viruses and their uses in nanotechnology. Drug Dev. Res. 2006, 67, 23-41. [CrossRef]

10. Young, M.; Willits, D.; Uchida, M.; Douglas, T. Plant viruses as biotemplates for materials and their use in nanotechnology. Annu. Rev. Phytopathol. 2008, 46, 361-384. [CrossRef]

11. Lee, S.Y.; Lim, J.S.; Harris, M.T. Synthesis and application of virus-based hybrid nanomaterials. Biotechnol. Bioeng. 2012, 109, 16-30. [CrossRef]

12. Hyman, P. Bacteriophages and nanostructured materials. Adv. Appl. Microbiol. 2012, 78, 55-73. [CrossRef] [PubMed]

13. Molek, P.; Bratkovič, T. Bacteriophages as scaffolds for bipartite display: Designing swiss army knives on a nanoscale. Bioconjug. Chem. 2015, 3, 367-378. [CrossRef] [PubMed]

14. Pires, D.P.; Cleto, S.; Sillankorva, S.; Azeredo, J.; Lu, T.K. Genetically engineered phages: A review of advances over the last decade. Microbiol. Mol. Biol. Rev. 2016, 80, 523-543. [CrossRef] [PubMed]

15. Ju, Z.; Sun, W. Drug delivery vectors based on filamentous bacteriophages and phage-mimetic nanoparticles. Drug Deliv. 2017, 24, 1898-1908. [CrossRef]

16. Kim, I.; Moon, J.S.; Oh, J.W. Recent advances in M13 bacteriophage-based optical sensing applications. Nano Converg. 2016, 3, 27. [CrossRef] [PubMed]

17. Lee, J.H.; Fan, B.; Samdin, T.D.; Monteiro, D.A.; Desai, M.S.; Scheideler, O.; Jin, H.E.; Kim, S.; Lee, S.W. Phage-based structural color sensors and their pattern recognition sensing system. ACS Nano 2017, 11, 3632-3641. [CrossRef]

18. Lee, S.W.; Belcher, A.M. Virus-based fabrication of micro- and nanofibers using electrospinning. Nano Lett. 2004, 4, 387-390. [CrossRef]

19. Merzlyak, A.; Indrakanti, S.; Lee, S.W. Genetically engineered nanofiber-like viruses for tissue regenerating materials. Nano Lett. 2009, 9, 846-852. [CrossRef]

20. Yang, S.H.; Chung, W.J.; McFarland, S.; Lee, S.W. Assembly of bacteriophage into functional materials. Chem. Rec. 2013, 13, 43-59. [CrossRef]

21. Lee, J.H.; Warner, C.M.; Jin, H.E.; Barnes, E.; Poda, A.R.; Perkins, E.J.; Lee, S.W. Production of tunable nanomaterials using hierarchically assembled bacteriophages. Nat. Protoc. 2017, 12, 1999-2013. [CrossRef] [PubMed]

22. Devaraj, V.; Han, J.; Kim, C.; Kang, Y.C.; Oh, J.W. Self-assembled nanoporous biofilms from functionalized nanofibrous M13 bacteriophage. Viruses 2018, 10, 322. [CrossRef] [PubMed]

23. Sawada, T.; Serizawa, T. Filamentous viruses as building blocks for hierarchical self-assembly toward functional soft materials. Bull. Chem. Soc. Jpn. 2018, 91, 455-466. [CrossRef]

24. Nam, K.T.; Peelle, B.R.; Lee, S.W.; Belcher, A.M. Genetically driven assembly of nanorings based on the M13 virus. Nano Lett. 2004, 4, 23-27. [CrossRef]

25. Bhardwaj, A.; Walker-Kopp, N.; Wilkens, S.; Cingolani, G. Foldon-guided self-assembly of ultra-stable protein fibers. Protein Sci. 2008, 17, 1475-1485. [CrossRef] [PubMed]

26. Guo, P. Bacterial virus phi29 DNA-packaging motor and its potential applications in gene therapy and nanotechnology. Methods Mol. Biol. 2005, 300, 285-324. [CrossRef] [PubMed]

27. Hyman, P.; Valluzzi, R.; Goldberg, E. Design of protein struts for self-assembling nanoconstructs. Proc. Natl. Acad. Sci. USA 2002, 99, 8488-8493. [CrossRef] [PubMed]

28. Daube, S.S.; Arad, T.; Bar-Ziv, R. Cell-free co-synthesis of protein nanoassemblies: Tubes, rings, and doughnuts. Nano Lett. 2007, 7, 638-641. [CrossRef]

29. Aksyuk, A.A.; Leiman, P.G.; Kurochkina, L.P.; Shneider, M.M.; Kostyuchenko, V.A.; Mesyanzhinov, V.V.; Rossmann, M.G. The tail sheath structure of bacteriophage T4: A molecular machine for infecting bacteria. EMBO J. 2009, 28, 821-829. [CrossRef]

30. Arisaka, F.; Yap, M.L.; Kanamaru, S.; Rossmann, M.G. Molecular assembly and structure of the bacteriophage T4 tail. Biophys. Rev. 2016, 8, 385-396. [CrossRef]

31. Fokine, A.; Rossmann, M.G. Molecular architecture of tailed double-stranded DNA phages. Bacteriophage 2014, 4, e28281. [CrossRef] [PubMed]

32. Leiman, P.G.; Shneider, M.M. Contractile tail machines of bacteriophages. Adv. Exp. Med. Biol. 2012, 726, 93-114. [CrossRef] [PubMed] 
33. Leiman, P.G.; Arisaka, F.; van Raaij, M.J.; Kostyuchenko, V.A.; Aksyuk, A.A.; Kanamaru, S.; Rossmann, M.G. Morphogenesis of the T4 tail and tail fibers. Virol. J. 2010, 7, 355. [CrossRef] [PubMed]

34. Kostyuchenko, V.A.; Chipman, P.R.; Leiman, P.G.; Arisaka, F.; Mesyanzhinov, V.V.; Rossmann, M.G. The tail structure of bacteriophage T4 and its mechanism of contraction. Nat. Struct. Mol. Biol. 2005, 12, 810-813. [CrossRef] [PubMed]

35. Kellenberger, E.; Boy de la Tour, E. On the fine structure of normal and "polymerized" tail sheath of phage T4. J. Ultrastruct. Res. 1964, 11, 545-563. [CrossRef]

36. Moody, M.F. Structure of the sheath of bacteriphage T4. I. Structure of the contracted sheath and polysheath. J. Mol. Biol. 1967, 25, 167-200. [CrossRef]

37. Tschopp, J.; Arisaka, F.; van Driel, R.; Engel, J. Purification, characterization and reassembly of the bacteriophage T4D tail sheath protein P18. J. Mol. Biol. 1979, 128, 247-258. [CrossRef]

38. Kurochkina, L.P.; Aksyuk, A.A.; Sachkova, M.Y.; Sykilinda, N.N.; Mesyanzhinov, V.V. Characterization of tail sheath protein of giant bacteriophage $\varphi K Z$ Pseudomonas aeruginosa. Virology 2009, 395, 312-317. [CrossRef]

39. To, C.M.; Kellenberger, Y.; Eisenstark, A. Disassembly of T-even bacteriophage into structural parts and subunits. J. Mol. Biol. 1969, 46, 493-511. [CrossRef]

40. Arisaka, F.; Engel, J.; Horst, K. Contraction and dissociation of the bacteriophage T4 tail sheath induced by heat and urea. Prog. Clin. Biol. Res. 1981, 64, 365-379.

41. Arisaka, F.; Takeda, S.; Funane, K.; Nashijima, N.; Ishii, S. Structural studies of the contractile tail sheath protein of bacteriophage T4. Structural analyses of the tail sheath protein, gp18, by limited proteolysis, immunoblotting, and immunoelectron microscopy. Biochemistry 1990, 29, 5057-5062. [CrossRef] [PubMed]

42. Poglazov, B.F.; Efimov, A.V.; Marco, S.; Carrascosa, J.; Kuznetsova, T.A.; Aijrich, L.G.; Kurochkina, L.P.; Mesyanzhinov, V.V. Polymerization of bacteriophage T4 tail sheath protein mutants truncated at the C-termini. J. Struct. Biol. 1999, 127, 224-230. [CrossRef] [PubMed]

43. Efimov, V.P.; Kurochkina, L.P.; Mesyanzhinov, V.V. Engineering of bacteriophage T4 tail sheath protein. Biochemistry 2002, 67, 1366-1370. [CrossRef] [PubMed]

44. Truncaite, L.; Šimoliūnas, E.; Zajanckauskaite, A.; Kaliniene, L.; Mankeviciute, R.; Staniulis, J.; Klausa, V.; Meskys, R. Bacteriophage vB_EcoM_FV3: A new member of "rV5-like viruses". Arch. Virol. 2012, 157, 2431-2435. [CrossRef] [PubMed]

45. Lowry, O.H.; Rosebrough, N.J.; Farr, A.L.; Randall, R.J. Protein measurement with the Folin phenol reagent. J. Biol. Chem. 1951, 193, 265-275.

46. Hellman, U.; Wernstedt, C.; Gonez, J.; Heldin, C.H. Improvement of an "in-gel" digestion procedure for the micro preparation of internal protein fragments for amino acid sequencing. Anal. Biochem. 1995, 224, 451-455. [CrossRef]

47. Ger, M.; Kaupinis, A.; Nemeikaite-Ceniene, A.; Sarlauskas, J.; Cicenas, J.; Cenas, N.; Valius, M. Quantitative proteomic analysis of anticancer drug RH1 resistance in liver carcinoma. Biochim. Biophys. Acta 2016, 1864, 219-232. [CrossRef]

48. Povilonienè, S.; Časaitè, V.; Bukauskas, V.; Šetkus, A.; Staniulis, J.; Meškys, R. Functionalization of $\alpha$-synuclein fibrils. Beilstein J. Nanotechnol. 2015, 6, 124-133. [CrossRef]

49. Transeq. Available online: http://www.ebi.ac.uk/Tools/st/emboss_transeq (accessed on 10 January 2019).

50. Clustal Omega. Available online: http://www.ebi.ac.uk/Tools/msa/clustalo (accessed on 10 January 2019).

51. Tamura, K.; Peterson, D.; Peterson, N.; Stecher, G.; Nei, M.; Kumar, S. MEGA5: Molecular evolutionary genetics analysis using maximum likelihood, evolutionary distance, and maximum parsimony methods. Mol. Biol. Evol. 2011, 28, 2731-2739. [CrossRef]

52. PIR. Available online: http://pir.georgetown.edu/pirwww/search/comp_mw.shtml (accessed on 10 January 2019).

53. Söding, J.; Biegert, A.; Lupas, A.N. The HHpred interactive server for protein homology detection and structure prediction. Nucleic Acids Res. 2005, 33, W244-W248. [CrossRef]

54. Zimmermann, L.; Stephens, A.; Nam, S.Z.; Rau, D.; Kubler, J.; Lozajic, M.; Gabler, F.; Söding, J.; Lupas, A.N.; Alva, V. A completely reimplemented mpi bioinformatics toolkit with a new HHpred server at its core. J. Mol. Biol. 2018, 430, 2237-2243. [CrossRef] [PubMed]

55. HHpred. Available online: https://toolkit.tuebingen.mpg.de/hhpred (accessed on 10 January 2019).

56. Zhang, Y. I-TASSER server for protein 3D structure prediction. BMC Bioinform. 2008, 9, 40. [CrossRef] [PubMed] 
57. I-TASSER. Available online: https:/ / zhanglab.ccmb.med.umich.edu/I-TASSER (accessed on 10 January 2019).

58. Pettersen, E.F.; Goddard, T.D.; Huang, C.C.; Couch, G.S.; Greenblatt, D.M.; Meng, E.C.; Ferrin, T.E. UCSF Chimera-a visualization system for exploratory research and analysis. J. Comput. Chem. 2004, 13, 1605-1612. [CrossRef] [PubMed]

59. UCSF Chimera. Available online: http:/ / www.rbvi.ucsf.edu/chimera (accessed on 10 January 2019).

60. Aksyuk, A.A.; Kurochkina, L.P.; Fokine, A.; Forouhar, F.; Mesyanzhinov, V.V.; Tong, L.; Rossmann, M.G. Structural conservation of the myoviridae phage tail sheath protein fold. Structure 2011, 19, 1885-1894. [CrossRef] [PubMed]

61. Novacek, J.; Siborova, M.; Benesik, M.; Pantucek, R.; Doskar, J.; Plevka, P. Structure and genome release of Twort-like Myoviridae phage with a double-layered baseplate. Proc. Natl. Acad. Sci. USA 2016, 113, 9351-9356. [CrossRef] [PubMed]

62. Sarris, P.F.; Ladoukakis, E.D.; Panopoulos, N.J.; Scoulica, E.V. A phage tail-derived element with wide distribution among both prokaryotic domains: A comparative genomic and phylogenetic study. Genome Biol. Evol. 2014, 6, 1739-1747. [CrossRef] [PubMed]

63. Kube, S.; Wendler, P. Structural comparison of contractile nanomachines. AIMS Biophys. 2015, 2, 88-115. [CrossRef]

64. Kudryashev, M.; Wang, R.Y.; Brackmann, M.; Scherer, S.; Maier, T.; Baker, D.; DiMaio, F.; Stahlberg, H.; Egelman, E.H.; Basler, M. Structure of the type VI secretion system contractile sheath. Cell 2015, 160, 952-962. [CrossRef]

65. Taylor, N.M.I.; van Raaij, M.J.; Leiman, P.G. Contractile injection systems of bacteriophages and related systems. Mol. Microbiol. 2018, 108, 6-15. [CrossRef]

66. Donelli, G.; Guglielmi, F.; Paoletti, L. Structure and physico-chemical properties of bacteriophage G. I. Arrangement of protein subunits and contraction process of tail sheath. J. Mol. Biol. 1972, 71, 113-125. [CrossRef]

67. Cremers, A.F.M.; Schepman, A.M.H.; Visser, M.P.; Mellema, J.E. An analysis of the contracted sheath structure of bacteriophage Mu. Eur. J. Biochem. 1977, 80, 393-400. [CrossRef] [PubMed]

68. Parker, M.L.; Eiserling, F.A. Bacteriophage SPO1 structure and morphogenesis. I. Tail structure and length regulation. J. Virol. 1983, 46, 239-249.

69. Muller, M.; Engel, A.; Aebi, U. Structural and physicochemical analysis of the contractive MM phage tail and comparison with the bacteriophage T4 tail. J. Struct. Biol. 1994, 112, 11-31. [CrossRef]

70. Fokine, A.; Battisti, A.J.; Bowman, V.D.; Efimov, A.V.; Kurochkina, L.P.; Chipman, P.R.; Mesyanzhinov, V.V.; Rossmann, M.G. Cryo-EM study of the Pseudomonas bacteriophage phiKZ. Structure 2007, 15, 1099-1104. [CrossRef] [PubMed]

71. Kurochkina, L.P.; Semenyuk, P.I.; Sykilinda, N.N.; Miroshnikov, K.A. The unique two-component tail sheath of giant Pseudomonas phage PaBG. Virology 2018, 515, 46-51. [CrossRef] [PubMed]

72. Kuznetsova, T.A.; Efimov, A.V.; Aijrich, L.G.; Kireeva, I.Y.; Marusich, E.I.; Cappuccinelli, P.; Fiori, P.; Rappelli, P.; Kurochkina, L.P.; Poglazov, B.F.; et al. Properties of recombinant bacteriophage T4 tail sheath protein and its deletion fragments. Biokhimia 1998, 63, 702-709.

73. Moody, M.F. Sheath of bacteriophage T4. III. Contraction mechanism deduced from partially contracted sheaths. J. Mol. Biol. 1973, 80, 613-635. [CrossRef]

74. Peissker, T.; Deschaume, O.; Rand, D.R.; Boyen, H.G.; Conard, T.; Van Bael, M.J.; Bartic, C. Selective protein immobilization onto gold nanoparticles deposited under vacuum on a protein-repellent self-sssembled monolayer. Langmuir 2013, 29, 15328-15335. [CrossRef]

75. Sharma, P.; Rathi, B.; Rodrigues, J.Y.; Gorobets, N. Self-assembled peptide nanoarchitectures: Applications and future aspects. Curr. Top. Med. Chem. 2015, 15, 1268-1289. [CrossRef]

76. Glover, D.J.; Giger, L.; Kim, S.S.; Naik, R.R.; Clark, D.S. Geometrical assembly of ultrastable protein templates for nanomaterials. Nat. Commun. 2016, 7, 11771. [CrossRef]

77. Knez, M.; Bittner, A.M.; Boes, F.; Wege, C.; Jeske, H.; Maiß, E.; Kern, K. Biotemplate synthesis of 3-nm nickel and cobalt nanowires. Nano Lett. 2003, 3, 1079-1082. [CrossRef]

78. Bromley, K.M.; Patil, A.J.; Perriman, A.W.; Stubbs, G.; Mann, S. Preparation of high quality nanowires by tobacco mosaic virus templating of gold nanoparticles. J. Mater. Chem. 2008, 18, 4796-4801. [CrossRef]

79. Warner, C.M.; Barker, N.; Lee, S.W.; Perkins, E.J. M13 bacteriophage production for large-scale applications. Bioprocess Biosyst. Eng. 2014, 37, 2067-2072. [CrossRef] [PubMed] 
80. Lane, L.C. Propagation and purification of RNA plant viruses. Methods Enzymol. 1986, 118C, $687-696$. [CrossRef]

81. Shih, S.M.H.; Doran, P.M. In vitro propagation of plant virus using different forms of plant tissue culture and modes of culture operation. J. Biotechnol. 2009, 143, 198-206. [CrossRef] [PubMed]

(C) 2019 by the authors. Licensee MDPI, Basel, Switzerland. This article is an open access article distributed under the terms and conditions of the Creative Commons Attribution (CC BY) license (http:/ / creativecommons.org/licenses/by/4.0/). 